\title{
Insulin resistance and associated factors in female adolescents from two capital cities in the north and south of Brazil
}

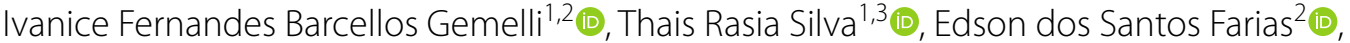 \\ Maria Teresa Anselmo Olinto ${ }^{1,4}$ and Poli Mara Spritzer ${ }^{1,3,5,6^{*}}$ (i)
}

\begin{abstract}
Background: It has been described that physiological changes in glucose metabolism, represented by insulin resistance $(\mathrm{IR})$, are predicted during pubertal evolution, and obesity may be associated with its persistence even at the end of puberty. The aim of this study was to investigate the prevalence of IR in female adolescents with possible associated factors and evaluate the relationship of time since menarche ( $<2 \mathrm{vs} . \geq 2$ years) in the occurrence of IR in two Brazilian capital cities: Porto Velho (RO) and Porto Alegre (RS).

Methods: This is a cross-sectional school-based study, using information from the Study of Cardiovascular Risks (ERICA) database for adolescents aged 12-17 years, enrolled in public and private schools, in municipalities with more than 100,000 inhabitants in Brazil, between 2013 and 2014. The present study included 889 adolescents, 382 in Porto Velho (PVh) and 507 in Porto Alegre (PoA). The homeostasis model assessment for insulin resistance (HOMA-IR) $\geq 3.16$ and fasting insulin $\geq 15 \mathrm{mU} / \mathrm{L}$ was used to determine the outcome variable of IR. Estimates of crude and adjusted prevalence ratios with confidence intervals of $95 \%$ were calculated using Poisson regression with robust variance. Sociodemographic, behavioral, reproductive and nutritional characteristics were considered as potential confounding factors in multivariable models based on a conceptual framework of IR determination.
\end{abstract}

Results: In the total sample, the prevalence of IR was $22.03 \%$ (95\% Cl 17.84-26.89). After adjusting the models, age 15-17 years and time since menarche $\geq 2$ years were found to act as protective factors for IR; in contrast, the highest probability of IR was observed in black adolescents, with increased waist circumference (WC) and overweight/obesity (Ow/Ob). The protective effect of two or more years since menarche (post-menarche) was observed for both higher HOMA-IR and fasting insulin in PVh; in PoA, such protection was maintained only for fasting insulin $\geq 15 \mathrm{mU} / \mathrm{L}$ after adjustments in the multivariate models.

Conclusions: IR is more prevalent during the peri-menarche period, especially in younger and black adolescents, compared to their white and post-menarche counterparts. The association between Ow/Ob and high WC with the occurrence of IR was independent of age and ethnicity variables.

Keywords: Menarche, Insulin resistance, Puberty, Adolescent, Obesity

*Correspondence: spritzer@ufrgs.br

${ }^{6}$ Division of Endocrinology, Hospital de Clínicas de Porto Alegre, Rua Ramiro Barcelos 2350, Porto Alegre, Rio Grande Do Sul 90035-003, Brazil

Full list of author information is available at the end of the article

\section{Background}

Insulin resistance (IR) is well reported to occur during puberty but the underlying mechanisms of physiological changes in glucose metabolism at this period are not entirely established [1-5]. Longitudinal studies have original author(s) and the source, provide a link to the Creative Commons licence, and indicate if changes were made. The images or other third party material in this article are included in the article's Creative Commons licence, unless indicated otherwise in a credit line to the material. If material is not included in the article's Creative Commons licence and your intended use is not permitted by statutory regulation or exceeds the permitted use, you will need to obtain permission directly from the copyright holder. To view a copy of this licence, visit http://creativecommons.org/licenses/by/4.0/. The Creative Commons Public Domain Dedication waiver (http://creativeco mmons.org/publicdomain/zero/1.0/) applies to the data made available in this article, unless otherwise stated in a credit line to the data. 
reported a transitory IR during pubertal evolution and a trend toward recover at the end of puberty [1-6].

It has also been shown that obesity not only affects the reduction in insulin sensitivity during puberty from early stages, but may also be associated with its persistence in the years following puberty [5, 6]. Given the global high prevalence of overweight and obesity in childhood and adolescence [7], this is a clinically relevant issue, since obesity and IR in young individuals are risk factors for pre-diabetes and diabetes mellitus (DM) in adulthood $[2-4,8]$.

While the relationship between puberty and IR has been reported in different studies, IR and time of menarche have been addressed less frequently [9], although emerging evidence suggests an association between excess weight and age at menarche $[10,11]$. According to studies conducted in Brazil, it differs from other countries in being such a large country, with significant demographic, cultural and ethnic diversity among its regions, such as in the north and south of the country $[12,13]$.

In face of the current worldwide prevalence of obesity, pubertal changes in glucose metabolism, and the fact that adolescents in northern Brazil are part of a lessrepresented studied group, which in contrast to the south is less urbanized, the aim of this study was to investigate the prevalence of IR in female adolescents and to evaluate the relationship with time since menarche $(<80.2 \mathrm{vs}$. $\geq 2$ years) and possible associated factors in the occurrence of IR.

\section{Materials and methods Study design and participants}

This is a cross-sectional study that used data from two centers, part of the Study of Cardiovascular Risks in Adolescents (ERICA 2013-2014). ERICA is a school-based, national, multicenter and cross-sectional study carried out in rural and urban contexts. The design of the ERICA study has been published previously (2015) [14]. Briefly, 73,624 students aged 12-17 years were enrolled from private and public schools, located in one of the $273 \mathrm{Bra}-$ zilian municipalities with more than 100,000 inhabitants [15]. For the present study, all female students from Porto Velho-RO (PVh) and Porto Alegre-RS (PoA), who participated in all research stages of ERICA and had already had menarche, were included.

This study was approved by the Research Ethics Committee (REC) of the Federal University of Rondônia, Federal University of Rio Grande do Sul and the Institute of Studies in Collective Health of the University of Rio de Janeiro (Protocol 45/2008), and was conducted according to the principles of the Helsinki declaration [16]. Written informed consent was obtained from each student and from his or her parents. The present study included a subsample of the students residing in two capitals: Porto Velho (PVh) and Porto Alegre (PoA), respectively, located in the Southern and Northern regions of Brazil.

\section{Data collection}

A self-administered questionnaire using a personal digital assistant (PDA, model LG GM750Q) was administered. Data regarding sociodemographic, behavioral and diet characteristics were obtained. The economic status was defined according to the Brazilian Association of Companies and Research (ABEP in the Portuguese acronym), as A1 (the highest social class), A2, B1, B2, C1, C2, $\mathrm{D}$ and $\mathrm{E}$ (the lowest social class) [17] data were grouped into 3 categories: A, B and C/D. Age was collected in full years and further grouped (12-13, 14, and 15-17 years. Ethnicity was defined by skin color as white and nonwhite (black, mixed or indigenous) [18, 19]. Smoking and alcohol consumption were assessed according to whether participants had already experimented them or not [1921]. Physical activity was categorized as inactive (students with no leisure-time, physical activity, or who exercised less than $300 \mathrm{~min} /$ week), or active for those who exercised from $\geq 300$ to $1200 \mathrm{~min} /$ week) [22]. Recommended screen time was up to $2 \mathrm{~h}$ per day, and not recommended was more than $2 \mathrm{~h}$ per day, according to the American Academy of Pediatrics guidelines [23]. Menarche was assessed according to age (age at menarche 9-12, or 13-16 years) and time since menarche, that is, peri-menarche: less than 2 years since menarche, and post-menarche: 2 years or more since menarche. This classification considered the expected time for maturation of the reproductive axis, after menarche, accepted as being more than 2 years of occurrence of the menarche event [24].

As for nutritional status, body mass index (BMI) was used. Height was assessed using a portable and demountable stadiometer, Alturexata ${ }^{\circledR}$ [25]. Body weight was assessed using a digital scale from Leader, model P150m, capacity of $200 \mathrm{~kg}$ and precision of $50 \mathrm{~g}$. BMI was defined by weight (kilograms) divided by square of the height (meters). The girls were stratified by overweight and obesity ( $\mathrm{z}$-score $>1)$ and normal weight groups ( $\mathrm{z}$-score $\leq 1$ ), according to BMI-for-age $z$-scores from the World Health Organization child growth standards [26]. Waist circumference was measured to the nearest $1 \mathrm{~mm}$ using a fiber glass anthropometric tape, with millimeter resolution and length of $1.5 \mathrm{~m}$ (Sanny ${ }^{\circledR}$, São Paulo, Brazil). WC classification followed the International Diabetes Federation (IDF) guidelines, which uses the 90th percentile as a cutoff point for girls up to 16 years old and $80 \mathrm{~cm}$ for those over 16 years old [27]. 
Dietary intake was assessed using a 24-h recall performed by trained interviewers. The food and drinks consumed were recorded in all meals and snacks before the interview in the dietary assessment software, ERICAREC $24 \mathrm{~h}$ [28]. Portion size estimation was obtained by showing photographs included in the software. Nutritional composition was calculated using the software database consisted of 1626 food items based on data from a Dietary National Survey carried out from 2008 to 2009 [29]. Energy and nutrients were estimated using the IBGE table [30].

Specifically for this study, nutritional characterization followed the dietary reference intake (DRI) [31] and presented total energy intake (Kcal), percentage of trans fatty acid (TFA), and ratio of omega- 6 to omega- 3 fatty acids. The three components were characterized according to mean intake in PVh and PoA.

\section{Outcome assessments}

Blood samples were collected after $12 \mathrm{~h}$ overnight fasting. Glucose was measured by the hexoquinase method; triglycerides, by enzymatic kinetics and HDL-cholesterol by enzymatic colorimetric assay (ADVIA 2400, Siemens). LDL- cholesterol was calculated by the Friedewald equation. Insulin was determined by chemiluminescence method (Modular Analytics-Roche) [32]. IR was calculated using the model of insulin homeostasis, HOMAIR Index as follows: insulin $(\mathrm{mU} / \mathrm{L}) \times($ glucose $(\mathrm{mg} /$ $\mathrm{dL}) \times 0.0555) / 22.5$, as proposed by Matthews et al. [33] . The $\geq 3.16$ cutoff point, according to the first guidelines for the prevention of atherosclerosis in childhood and adolescence [31], was used in our analysis. Fasting insulin, with a cutoff of $\geq 15 \mathrm{mU} / \mathrm{mL}$ was also assessed as an additional marker of IR [34].

\section{Statistical analysis}

Demographic, nutritional, anthropometric, and biochemical variables were expressed as a percentage and 95\% confidence interval (CI). The differences between the cities were assessed using the student $t$ test for continuous variables and the chi-square test for dichotomous variables.

All factors with IR associated were converted to categorical variables to enable the comparability of prevalence ratios (PRs). In the evaluation of unadjusted and adjusted measures of effect in the multivariate models, Poisson regression with robust variance was used. The adjusted analysis followed a conceptual model defined a priori [35]. Variables that were associated with outcomes at a significance level of $\leq 20 \%$ in the unadjusted analysis were included in the multivariate model as potential confounders. At level I, the most distal level of determination, sociodemographic variables were included; at level II, the reproductive and behavioral ones; and at level III, the most proximal, the nutritional status variables. Finally, variables with a $p$ value of $\leq 0.05$ were considered associated with the outcomes, that is, IR (insulin levels and HOMA-IR). Due to the collinearity between WC and overweight/obesity $(\mathrm{Ow} / \mathrm{Ob})$, these two variables of nutritional status were entered into different models, model 1 and model 2, respectively (shown in Fig. 1).

In addition, the multivariate-adjusted Poisson regression model with robust estimates was used to assess the association among the subgroups of time since menarche (peri-menarche and post-menarche) in each city with demographic, lifestyle, anthropometric factors and IR.

Statistical analyzes were performed using the statistical software STATA, version 14 (Stata Corporation, College Station, TX, USA).

\section{Results}

A total of 889 female adolescents between 12 and 17 years of age were included, 382 in PVh and 507 in PoA, mean age was 14.27 (95\% CI 14.21-14.34) and 14.58 years (95\% CI 14.50-14.65) in the north and south of Brazil, respectively. Table 1 shows a comparison of the sample between the two capitals, according to sociodemographic, reproductive, behavioral, nutritional status

\begin{tabular}{lll}
\hline & \multicolumn{1}{c}{ Model 1 } & \multicolumn{1}{c}{ Model 2 } \\
\hline Level 1 & Demographics and Economic Class & Demographics and Economic Class \\
& Reproductive variables (Time since & Reproductive variables (Time since \\
Level 2 & menarche $<2$ years and $\geq 2$ years & menarche $<2$ years and $\geq 2$ years \\
& Age at menarche) & Age at menarche) \\
Level 3 & Behavioral & Behavioral \\
Outcome & IR & Waist circumference \\
\hline
\end{tabular}

Fig. 1 Conceptual model 
Table 1 Characterization of adolescents in the sample by capital, according to sociodemographic, reproductive, behavioral and nutritional variables, Porto Velho and Porto Alegre, 2013/2014 ( $n=889)$

\begin{tabular}{|c|c|c|c|c|c|}
\hline \multirow[t]{2}{*}{ Characteristics (889) } & \multirow[t]{2}{*}{$\mathbf{n}$} & Porto Velho (382) & \multirow[t]{2}{*}{$\mathbf{n}$} & Porto Alegre (507) & \multirow[t]{2}{*}{$p$-value } \\
\hline & & & & $\%(95 \% \mathrm{Cl})$ & \\
\hline \multicolumn{6}{|l|}{ Sociodemographic characteristics } \\
\hline \multicolumn{6}{|l|}{ Chronological age } \\
\hline $12-13$ years & 94 & $36.51(34.62-38.45)$ & 97 & $30.22(28.24-32.27)$ & \multirow[t]{3}{*}{$<0.001$} \\
\hline 14 years & 74 & $19.83(18.68-21.02)$ & 117 & $17.75(17.12-18.39)$ & \\
\hline $15-17$ years & 214 & $43.66(42.19-45.14)$ & 293 & $52.03(50.47-53.59)$ & \\
\hline \multicolumn{6}{|l|}{ Ethnicity } \\
\hline White & 120 & $27.77(23.14-32.92)$ & 359 & $67.27(58.5-74.97)$ & \multirow[t]{3}{*}{$<0.001$} \\
\hline Black & 13 & $3.14(1.8-5.41)$ & 38 & $11.54(7.31-17.74)$ & \\
\hline Other & 238 & $69.09(63.27-74.37)$ & 104 & $21.2(15.88-27.7)$ & \\
\hline \multicolumn{6}{|l|}{ Economic class } \\
\hline A & 22 & $6.51(3.4-11.79)$ & 76 & $17.36(9.26-30.17)$ & \multirow[t]{3}{*}{0.019} \\
\hline B & 171 & $57.83(47.84-67.22)$ & 227 & $59.12(50.54-67.18)$ & \\
\hline$C / D$ & 93 & $35.66(25.66-47.09)$ & 89 & $23.52(17.81-30.4)$ & \\
\hline \multicolumn{6}{|l|}{ Reproductive characteristics } \\
\hline \multicolumn{6}{|l|}{ Age at menarche } \\
\hline $9-12$ years & 278 & 76.42 (71.88-80.43) & 382 & $79.95(75.44-83.81)$ & \multirow[t]{2}{*}{0.241} \\
\hline $13-16$ years & 104 & $23.58(19.57-28.12)$ & 125 & $20.05(16.19-24.56)$ & \\
\hline \multicolumn{6}{|l|}{ Time of menarche } \\
\hline$<2$ years & 91 & $32.34(28.36-36.59)$ & 91 & $25.47(20.01-31.83)$ & \multirow[t]{2}{*}{0.069} \\
\hline$\geq 2$ years & 291 & $67.66(63.41-71.64)$ & 416 & $74.53(68.17-79.99)$ & \\
\hline \multicolumn{6}{|l|}{ Behavioral characteristics } \\
\hline \multicolumn{6}{|l|}{ Smoking } \\
\hline Yes & 71 & $17.4(13.6-22)$ & 147 & $30.08(23.83-37.17)$ & \multirow[t]{2}{*}{0.001} \\
\hline No & 311 & $82.6(78-86.4)$ & 360 & $69.92(62.83-76.17)$ & \\
\hline \multicolumn{6}{|l|}{ Alcohol } \\
\hline Yes & 181 & $47.01(42.06-52.02)$ & 381 & 79.51 (72.78-84.92) & \multirow[t]{2}{*}{0.001} \\
\hline No & 173 & $52.99(47.98-57.94)$ & 97 & $20.49(15.08-27.22)$ & \\
\hline \multicolumn{6}{|l|}{ Screen hours } \\
\hline$<2$ h/day & 177 & $54.5(47.56-61.27)$ & 133 & $31.21(25.56-37.49)$ & \multirow[t]{2}{*}{$<0.001$} \\
\hline$\geq 2$ h/day & 172 & $45.5(38.73-52.44)$ & 327 & $68.79(62.51-74.44)$ & \\
\hline Physical activity & & & & & \\
\hline Active & 156 & $44.16(36.44-52.17)$ & 186 & $34.34(28.48-40.73)$ & 0.053 \\
\hline Inactive & 205 & $55.84(47.83-63.56)$ & 301 & $65.66(59.27-71.52)$ & \\
\hline Nutritional status & & & & & \\
\hline Nutritional status (\%) & & & & & \\
\hline Low weight and normal weight & 294 & $77.11(69.17-83.49)$ & 345 & $65.68(58.59-72.13)$ & 0.028 \\
\hline Overweight/obesity & 88 & $22.89(16.51-30.83)$ & 162 & $34.32(27.87-41.41)$ & \\
\hline Waist circumference & & & & & \\
\hline Normal & 332 & $87.93(81.66-92.26)$ & 423 & $84.39(80.17-87.85)$ & 0.296 \\
\hline Elevated & 50 & $12.07(7.74-18.34)$ & 84 & $15.61(12.15-19.83)$ & \\
\hline$\overline{\text { Diet }}$ & & Mean (standard error) & & Mean (standard error) & \\
\hline$\overline{\text { Energy (Kcal) }}$ & & $2238.617(85.43)$ & & $1923.761(60.83)$ & 0.005 \\
\hline Omega-6: omega-3 ratio & & $8.21(0.20)$ & & $8.97(0.40)$ & 0.099 \\
\hline Trans-fat & & $0.91(0.77)$ & & $1.26(0.63)$ & 0.001 \\
\hline
\end{tabular}

Student $t$ test, mean and standard error and chi-square, $95 \% \mathrm{Cl}$. Smoking: yes = already experimented; Alcohol: yes =already experimented; Physical activity: inactive =0-300 min/wk.; Screen hours: not recommended=more than $2 \mathrm{~h} /$ day; Nutritional status classification according to BMI-for-age z-score (WHO, [49]); Waist circumference; Altered blood glucose (IDF, [48]); Energy expressed by daily intake in Kcal, Omega- 6 : Omega- 3 ratio and Trans-fat cutoff point established by the dietary reference intakes (DRI, [31]). Eco Class D: Corresponded to $1.04 \%$ of the total sample (2.21\% of the sample in Porto Velho and 0.67\% in Porto Alegre) Sample N: Ethnicity $n=872$, economic class $n=678$, alcohol $n=832$, physical activity $n=848$

Statistically significant differences between capitals are in bold $(p<0.05)$ 
and food consumption variables. There was a higher percentage of older adolescents (15-17 years), of adolescents classified as white, and belonging to economic class $\mathrm{A}$ in the city of PoA, when compared to PVh. Although, in both cities, almost $60 \%$ of adolescents belonged to economic class B. Regarding behavior, adolescents in PoA presented a higher prevalence of smoking, alcohol consumption and screen time compared to those in PVh.

Also in Table 1, it is observed that $\mathrm{Ow} / \mathrm{Ob}$ was also higher in PoA compared to PVh. As for the indicators used for quality of diet, there was a higher caloric intake in PVh, but a higher mean consumption of trans-fat in PoA.

The prevalence of HOMA-IR $(\geq 3.16)$ in the total sample was $22.03 \%$ (95\% CI 17.84-26.89), being $18.22 \%$ (95\% CI $11.69-27,27)$ and $23.33 \%$ (95\% CI 18.32-29.21), in PVh and PoA, respectively-data not shown in the table.

Table 2 shows the prevalence and PRs for IR (HOMA$I R \geq 3.16$ ), according to the characteristics of the sample. In both capitals, there is a protective relationship for IR in the group of adolescents aged 15-17 years, compared with the younger ones, as well as in the group with time since menarche of two or more years, compared with those with time since menarche of less than two years, being $54 \%$ and $45 \%$ in PVh and PoA, respectively. This protection corresponded to $47 \%$ when considering the total sample (Additional file 1: Table S1). Also in both capitals, girls with $\mathrm{Ow} / \mathrm{Ob}$ and those with altered $\mathrm{WC}$ were more likely to have IR. Difference in relation to ethnicity was observed only in the southern capital, PoA, where IR was more likely to occur in black adolescents.

The prevalence of hyperinsulinemia (insulin $\geq 15 \mathrm{mU} /$ $\mathrm{mL}$ ) in the total sample was $6.52 \%$ (95\% CI 4.35-9.65), being $8.41 \%$ (95\% CI $4.54-15.09$ ) and 5.87\% (95\% CI 3.49-9.72), in PVh and PoA, respectively-data not shown in the table.

Table 3 shows the prevalence and PRs for hyperinsulinemia, according to the characteristics of the sample. There is a protective relationship for the group of adolescents with time since menarche of two or more years, compared to those with less than two years since menarche, observed in PoA. This relationship was of marginal statistical significance in PVh. Hyperinsulinemia were also more likely to occur in adolescents classified as black in PoA. Adolescents with behavioral characteristics, such as experimenting with tobacco and alcohol, were more likely to present hyperinsulinemia only in PVh.

As for nutritional status, $\mathrm{Ow} / \mathrm{Ob}$ and greater $\mathrm{WC}$ showed an increased probability for the occurrence of hyperinsulinemia in the two capitals. The strength of the association was greater in adolescents in PVh for the two outcomes, IR and hyperinsulinemia (Tables 2 and 3 ).
Table 4 shows the PR for IR, after adjustment in the multivariate models in both capitals. The age of 15-17 years, that is, late adolescence and the time since menarche $\geq 2$ years were protective factors for both HOMA and hyperinsulinemia; on the other hand, the highest probability of both outcomes was observed both in black adolescents, with greater $\mathrm{WC}$ and Ow/Ob. Cityspecific multivariate models are available in Additional file 1: Tables S2 and S3.

Table 5 presents adjusted models, stratified by PVh and by PoA comparing time since menarche. The protective effect of 2 years or more since menarche was observed for both HOMA-IR and fasting insulin in PVh, even after adjustments in the four models. In PoA only in the unadjusted model, protection for HOMA-IR was present, however, for fasting insulin such protection was maintained even after adjustment for age, ethnicity, smoking, alcohol, $\mathrm{WC}$ and $\mathrm{Ow} / \mathrm{Ob}$.

Supplementary material also shows the distribution of dietary components according to the presence of IR in the two capitals (Additional file 1: Table S4), followed by prevalence of IR according to time since menarche (Additional file 2: Table S5).

\section{Discussion}

In the present study with adolescents from two Brazilian regions, the prevalence of IR was $22 \%$ and age between 15 and 17 years and time since menarche $\geq 2$ years were protective factors for IR. In turn, the highest probability of IR was observed in black adolescents, with increased WC circumference and $\mathrm{Ow} / \mathrm{Ob}$.

The prevalence of IR has been assessed in other countries, and a wide range of values (from 3.1\% in Greece to $44 \%$ in New Zealand) has been reported. Indeed, specific characteristics in each study, such as the age of the adolescent population and criteria used to define IR at each age may have influenced on this variation [31]. Similar to our findings, one study with Brazilian female adolescents using the 75th percentile of the HOMA-IR found a $27.8 \%$ prevalence of IR [9].

In this sense, in the current study, the general sample involved both eutrophic and $\mathrm{Ow} / \mathrm{Ob}$ adolescents, which may have impacted on the prevalence of IR [7] Besides, the prevalence of IR may have been further attenuated as a result of the choice of the HOMA cutoff point, as shown in a meta-analysis, in which the lowest prevalence was demonstrated in a study that used a HOMA cutoff of 3.16 , and when using 2.1 , the prevalence increased twofold [36].

Interestingly, we found no difference in the prevalence of IR among female adolescents living in the two Brazilian regions, with notorious environmental and cultural diversity. The similarity of the outcome between the two 
Table 2 Prevalence and prevalence ratio of insulin resistance according to sociodemographic, reproductive, behavioral and nutritional characteristics, Porto Velho and Porto Alegre, 2013/2014 ( $n=889)$

\begin{tabular}{|c|c|c|c|c|c|c|}
\hline \multirow[t]{3}{*}{ Characteristics } & \multicolumn{6}{|l|}{ HOMA-IR $\geq 3.16$} \\
\hline & \multicolumn{3}{|l|}{ Porto Velho } & \multicolumn{3}{|l|}{ Porto Alegre } \\
\hline & $\%(\mathrm{Cl})$ & $\mathrm{PR}(\mathrm{Cl})$ & PR p value & $\%(\mathrm{Cl})$ & PR (CI) & PR p value \\
\hline \multicolumn{7}{|l|}{ Sociodemographic characteristics } \\
\hline \multicolumn{7}{|l|}{ Chronological age } \\
\hline $12-13$ years & $25.26(13.64-41.97)$ & 1 & 1 & $32.2(21.98-44.47)$ & 1 & 1 \\
\hline 14 years & $16.7(7.66-32.65)$ & $0.66(0.31-1.41)$ & 0.263 & $21.12(12.65-33.11)$ & $0.65(0.36-1.16)$ & 0.144 \\
\hline $15-17$ years & $12.95(7.87-20.58)$ & $0.51(0.28-0.92)$ & 0.028 & $18.84(12.96-26.57)$ & $0.58(0.35-0.95)$ & 0.035 \\
\hline \multicolumn{7}{|l|}{ Ethnicity } \\
\hline White & $18.34(9.89-31.48)$ & 1 & 1 & $17.48(11.89-24.95)$ & 1 & 1 \\
\hline Black & $14.54(1.98-58.84)$ & $0.80(0.11-5.71)$ & 0.818 & $45.49(27.33-64.94)$ & $2.59(1.36-4.94)$ & 0.005 \\
\hline Other & $18.97(11.54-29.59)$ & $1.03(0.59-1.77)$ & 0.906 & $29.77(21.57-39.52)$ & $1.69(1.03-2.79)$ & 0.038 \\
\hline \multicolumn{7}{|l|}{ Economic class } \\
\hline A & $14.96(4.59-39.15)$ & 1 & 1 & $16.55(6.44-36.33)$ & 1 & 1 \\
\hline B & 19.64 (13.71-27.33) & $1.22(0.26-5.55)$ & 0.781 & $27.19(21.11-34.26)$ & $1.63(0.55-4.83)$ & 0.357 \\
\hline$C / D$ & $17.22(7.22-35.75)$ & $1.05(0.17-6.57)$ & 0.949 & $23.49(13.13-38.42)$ & $1.42(0.38-5.19)$ & 0.580 \\
\hline \multicolumn{7}{|l|}{ Reproductive characteristics } \\
\hline \multicolumn{7}{|l|}{ Age at menarche } \\
\hline $9-12$ years & $19.91(12.26-30.65)$ & $1.59(0.75-3.36)$ & 0.207 & $23.39(17.94-29.9)$ & $1.02(0.62-1.67)$ & 0.921 \\
\hline $13-16$ years & $12.54(5.61-25.68)$ & 1 & 1 & $22.84(13.94-35.1)$ & 1 & 1 \\
\hline \multicolumn{7}{|l|}{ Time of menarche } \\
\hline$<2$ years & $28.31(13.43-50.14)$ & 1 & 1 & $34.96(25.11-46.29)$ & 1 & 1 \\
\hline$\geq 2$ years & $13.34(8.73-19.85)$ & $0.46(0.24-0.90)$ & 0.027 & $19.28(13.99-25.98)$ & $0.55(0.35-0.84)$ & 0.008 \\
\hline \multicolumn{7}{|l|}{ Behavioral characteristics } \\
\hline \multicolumn{7}{|l|}{ Smoking } \\
\hline Yes & $29.76(13.69-53.09)$ & $1.89(0.79-4.48)$ & 0.136 & $20.1(13.67-28.67)$ & $0.81(0.48-1.35)$ & 0.414 \\
\hline No & $15.76(8.99-26.16)$ & 1 & 1 & $24.64(17.69-33.23)$ & 1 & 1 \\
\hline \multicolumn{7}{|l|}{ Alcohol } \\
\hline Yes & $23.11(14.61-34.54)$ & $1.48(0.90-2.43)$ & 0.110 & $21.76(16.09-28.75)$ & $0.67(0.42-1.07)$ & 0.097 \\
\hline No & $15.47(8.96-25.4)$ & 1 & 1 & $31.89(20.68-45.68)$ & 1 & 1 \\
\hline \multicolumn{7}{|l|}{ Screen hours } \\
\hline$<2$ h/day & $24.46(15.14-36.76)$ & 1 & 1 & $19.48(11.87-30.31)$ & 1 & 1 \\
\hline$\geq 2$ h/day & $18.26(12.67-25.6)$ & $0.75(0.43-1.32)$ & 0.313 & $25.38(18.9-33.17)$ & $1.29(0.71-2.37)$ & 0.378 \\
\hline \multicolumn{7}{|l|}{ Physical activity } \\
\hline Active & $18.5(11.48-28.42)$ & 1 & 1 & $21.47(15.48-29)$ & 1 & 1 \\
\hline Inactive & $17.55(9.81-29.39)$ & $1.05(0.56-1.93)$ & 0.865 & $22.02(15.21-30.78)$ & $0.97(0.61-1.56)$ & 0.928 \\
\hline \multicolumn{7}{|l|}{ Nutritional status } \\
\hline \multicolumn{7}{|l|}{ Nutritional status (\%) } \\
\hline Low weight and normal weight & $9.48(4.51-18.84)$ & 1 & 1 & $18.84(13.76-25.26)$ & 1 & 1 \\
\hline Overweight/obesity & $48(37.28-58.82)$ & $5.04(2.53-10.05)$ & $<0.001$ & $31.77(24.81-39.66)$ & $1.68(1.26-2.24)$ & 0.001 \\
\hline \multicolumn{7}{|l|}{ Waist circumference } \\
\hline Normal & $12.47(6.87-21.56)$ & 1 & 1 & $20.05(15.22-25.94)$ & 1 & 1 \\
\hline Elevated & $61.21(42.81-76.89)$ & $4.90(2.53-9.48)$ & $<0.001$ & $40.69(27.41-55.48)$ & $2.02(1.37-2.99)$ & 0.001 \\
\hline
\end{tabular}

Chi-square test $95 \% \mathrm{Cl}$. Robust Poisson regression $\mathrm{p}$ value $<0.05$; Time since menarche $<2$ years since the occurrence of menarche, and $\geq 2$ years since the occurrence of menarche; Ethnicity: white, black and other (indigenous, mixed and yellow). Smoking: yes = already experimented; Alcohol: yes =already experimented; Physical activity: inactive $=0$ to $300 \mathrm{~min} / \mathrm{wk}$;; Screen hours: not recommended = more than $2 \mathrm{~h} /$ day Nutritional status classification according to BMl-for-age $\mathrm{z}$-score (WHO, [49]); Waist circumference (IDF, [48]); HOMA-IR $\geq 3.16$ (I Diretriz de prevenção da aterosclerose na infância e adolescência, [50])

Statistically significant prevalence ratios are in bold $(p<0.05)$ 
Table 3 Prevalence and prevalence ratio of hyperinsulinemia according to sociodemographic, reproductive, behavioral and nutritional characteristics, Porto Velho and Porto Alegre, 2013/2014 ( $n=889)$

\begin{tabular}{|c|c|c|c|c|c|c|}
\hline \multirow[t]{3}{*}{ Characteristics } & \multicolumn{6}{|l|}{ Insulin $\geq 15 \mathrm{mU} / \mathrm{mL}$} \\
\hline & \multicolumn{3}{|l|}{ Porto Velho } & \multicolumn{3}{|l|}{ Porto Alegre } \\
\hline & $\%(\mathrm{Cl})$ & $\mathrm{PR}(\mathrm{Cl})$ & PR p value & $\%(\mathrm{Cl})$ & PR (Cl) & PR p value \\
\hline \multicolumn{7}{|l|}{ Sociodemographic characteristics } \\
\hline \multicolumn{7}{|l|}{ Chronological age } \\
\hline $12-13$ years & $21.1(11.05-6.53)$ & 1 & & $27.3(16.69-41.32)$ & 1 & \\
\hline 14 years & $17.77(6.61-39.74)$ & $0.84(0.32-2.21)$ & 0.711 & $19.42(11.78-30.31)$ & $0.71(0.34-1.44)$ & 0.334 \\
\hline $15-17$ years & $13.41(8.33-20.91)$ & $0.63(0.34-1.17)$ & 0.135 & $15.86(11.5-21.48)$ & $0.58(0.32-1.03)$ & 0.062 \\
\hline \multicolumn{7}{|l|}{ Ethnicity } \\
\hline White & $16.13(8.25-29.14)$ & 1 & & $15.25(10.55-21.54)$ & 1 & \\
\hline Black & $14.55(1.99-58.84)$ & $0.91(0.13-6.34)$ & 0.926 & $40.06(21.14-64.04)$ & $2.68(1.23-5.81)$ & 0.015 \\
\hline Other & 18.21(10.77-29.11) & $1.12(0.58-2.17)$ & 0.708 & $23.53(15.58-33.9)$ & $1.53(0.85-2.76)$ & 0.147 \\
\hline \multicolumn{7}{|l|}{ Economic class } \\
\hline A & 12.05(4.19-30.01) & 1 & & $14.91(5.55-34.34)$ & 1 & \\
\hline B & 19.75(13.65-27.71) & $1.55(0.35-6.72)$ & 0.532 & $25.65(19.68-32.7)$ & $1.71(0.51-5.65)$ & 0.361 \\
\hline$C / D$ & $18.86(8.06-38.14)$ & $1.45(0.25-8.18)$ & 0.652 & $19.78(11.72-31.4)$ & $1.32(0.35-4.92)$ & 0.661 \\
\hline \multicolumn{7}{|l|}{ Reproductive characteristics } \\
\hline \multicolumn{7}{|l|}{ Age at menarche } \\
\hline $9-12$ years & 18.91(11.57-29.37) & $1.70(0.79-3.69)$ & 0.160 & $20.7(15.45-27.17)$ & $1.21(0.68-2.16)$ & 0.484 \\
\hline $13-16$ years & 11.05(4.7-23.82) & 1 & & $16.96(10.56-26.1)$ & 1 & \\
\hline \multicolumn{7}{|l|}{ Time of menarche } \\
\hline$<2$ years & $23.92(1.18-42.48)$ & 1 & & $32.7(22.62-44.68)$ & 1 & \\
\hline$\geq 2$ years & 13.82(8.79-21.08) & $0.57(0.32-1.02)$ & 0.061 & $15.59(11.72-25.08)$ & $0.47(0.30-0.74)$ & 0.002 \\
\hline \multicolumn{7}{|l|}{ Behavioral characteristics } \\
\hline \multicolumn{7}{|l|}{ Smoking } \\
\hline Yes & $31.78(15.27-54.64)$ & $2.27(1.09-4.73)$ & 0.030 & $16.1(10.11-24.65)$ & $0.74(0.40-1.36)$ & 0.327 \\
\hline No & 14(8.2-26.42) & 1 & & $21.61(15.39-29.47)$ & 1 & \\
\hline \multicolumn{7}{|l|}{ Alcohol } \\
\hline Yes & $22.04(13.51-3.85)$ & $1.52(1.04-2.23)$ & 0.031 & $20.19(15.05-26.54)$ & $0.79(0.49-1.29)$ & 0.344 \\
\hline No & 14.29(8.71-22.58) & 1 & & $25.16(15.86-37.49)$ & 1 & \\
\hline \multicolumn{7}{|l|}{ Screen hours } \\
\hline$<2$ h/day & $21.94(14.02-2.63)$ & 1 & & $17.84(10.4-28.88)$ & 1 & \\
\hline$\geq 2$ h/day & 18.04(11.11-7.94) & $0.83(0.46-1.50)$ & 0.537 & $22.34(16.62-29.33)$ & $1.23(0.63-2.40)$ & 0.513 \\
\hline \multicolumn{7}{|l|}{ Physical activity } \\
\hline Active & $17.66(11.41-6.31)$ & 1 & & 21.33(15.12-29.21) & 1 & \\
\hline Inactive & 15.94(8.2-28.7) & $1.10(0.56-2.17)$ & 0.747 & $16.76(11.59-23.61)$ & $1.27(0.78-2.07)$ & 0.308 \\
\hline \multicolumn{7}{|l|}{ Nutritional status } \\
\hline \multicolumn{7}{|l|}{ Nutritional status (\%) } \\
\hline Low weight and normal weight & $8.2(3.72-17.13)$ & 1 & & $14.76(10.54-20.29)$ & 1 & \\
\hline Overweight/obesity & $47.17(35.27-9.39)$ & $5.74(2.68-12.28)$ & $<0.001$ & $29.92(22.59-38.45)$ & $2.02(1.39-2.93)$ & 0.001 \\
\hline \multicolumn{7}{|l|}{ Waist circumference } \\
\hline Normal & $11.55(6.45-19.83)$ & 1 & & $16.39(11.74-22.4)$ & 1 & \\
\hline Elevated & $57.91(36.52-76.7)$ & $5.00(2.54-9.8)$ & $<0.001$ & $39.19(26.25-53.85)$ & $2.38(1.42-4.01)$ & 0.002 \\
\hline
\end{tabular}

Chi-square test $95 \% \mathrm{Cl}$. Robust Poisson regression $\mathrm{p}$ value $<0.05$; Time since menarche $<2$ years since the occurrence of menarche, and $\geq 2$ years since the occurrence of menarche; Ethnicity: white, black and other (indigenous, mixed and yellow). Smoking:yes =already experimented; Alcohol: yes=already experimented; Physical activity: inactive $=0-300 \mathrm{~min} /$ wk.; Screen hours: not recommended = more than $2 \mathrm{~h} /$ day Nutritional status classification according to BMI-for-age $\mathrm{z}$-score (WHO, [49]); Waist circumference (IDF, [48]); Insulin $\geq 15 \mathrm{mU} / \mathrm{mL}$ (I Diretriz de prevenção da aterosclerose na infância e adolescência, [50])

Statistically significant prevalence ratios are in bold $(p<0.05)$ 
Table 4 Adjusted prevalence ratio of factors associated with insulin resistance in the total sample

\begin{tabular}{|c|c|c|c|c|}
\hline & \multicolumn{4}{|c|}{ Porto Velho and Porto Alegre (889) } \\
\hline & \multicolumn{2}{|l|}{ HOMA-IR } & \multicolumn{2}{|l|}{ Insulin } \\
\hline & Adjusted & $P$ value & Adjusted & $P$ value \\
\hline \multicolumn{5}{|l|}{ Level 1} \\
\hline \multicolumn{5}{|l|}{ Age } \\
\hline $12-13$ years & 1 & & 1 & \\
\hline 14 years & $0.72(0.45-1.15)$ & 0.173 & $0.82(0.45-1.48)$ & 0.508 \\
\hline $15-17$ years & $0.59(0.40-0.88)$ & 0.012 & $0.62(0.40-0.96)$ & 0.036 \\
\hline \multicolumn{5}{|l|}{ Ethnicity } \\
\hline Black & $2.36(1.29-4.31)$ & 0.006 & $2.47(1.20-5.08)$ & 0.015 \\
\hline Others & $1.28(0.85-1.91)$ & 0.217 & $1.27(0.81-1.99)$ & 0.289 \\
\hline \multicolumn{5}{|l|}{ Level 2} \\
\hline \multicolumn{5}{|l|}{ Time since menarche } \\
\hline$\geq 2$ years & $0.64(0.42-0.97)$ & 0.039 & $0.53(0.37-0.76)$ & 0.001 \\
\hline \multicolumn{5}{|l|}{ Level 3} \\
\hline \multicolumn{5}{|l|}{ Model 1} \\
\hline \multicolumn{5}{|l|}{ Waist circumference } \\
\hline Altered & $2.58(1.97-3.38)$ & $<0.001$ & $2.95(2.08-4.19)$ & $<0.001$ \\
\hline \multicolumn{5}{|l|}{ Model 2} \\
\hline \multicolumn{5}{|l|}{ Nutritional status } \\
\hline Overweight and obesity & $2.08(1.58-2.73)$ & $<0.001$ & $2.50(1.81-3.46)$ & $<0.001$ \\
\hline
\end{tabular}

Poisson regression; $\mathrm{P}$ value $\leq 0.05$ and $95 \% \mathrm{Cl} ; \mathrm{IR}=\mathrm{HOMA} \geq 3.16$, Insulin $\geq 15 \mathrm{mU} / \mathrm{mL}$ (I Diretriz de prevenção da aterosclerose na infância e adolescência, [50]). Model 1 included waist circumference and model 2 included overweight and obesity; Ethnicity: white (reference), black and others (indigenous, mixed and yellow); Group Menarche $\geq 2$ years: 2 years or more since menarche; Reference: category $=1$ (Less than 2 years since menarche); altered waist circumference $>90$ th percentile or $\geq 80 \mathrm{~cm}$ (IDF, [48]); nutritional status classification according to BMl-for-age z-score (WHO, [49])

Statistically significant prevalence ratios are in bold $(p<0.05)$

Table 5 Prevalence ratios of insulin resistance, altered HOMA-IR and hyperinsulinemia, according to time since menarche

\begin{tabular}{|c|c|c|c|c|c|}
\hline & \multirow{2}{*}{$\begin{array}{l}\text { Porto Velho (382) } \\
\text { Post-menarche }\end{array}$} & \multirow[t]{3}{*}{ p value } & \multicolumn{2}{|c|}{ Porto Alegre (507) } & \multirow{3}{*}{$\begin{array}{l}p \\
\text { value }\end{array}$} \\
\hline & & & Peri-menarche & Post-menarche & \\
\hline & PR & & Reference & PR & \\
\hline \multicolumn{6}{|l|}{ HOMA-IR } \\
\hline Mod. 1 & $0.46(0.21-1.04)$ & 0.062 & 1 & $0.55(0.34-0.87)$ & 0.013 \\
\hline Mod. 2 & $0.60(0.31-1.16)$ & 0.122 & 1 & $0.64(0.34-1.20)$ & 0.160 \\
\hline Mod. 3 & $0.53(0.29-0.96)$ & 0.038 & 1 & $0.64(0.38-1.07)$ & 0.090 \\
\hline Mod. 4 & $0.49(0.24-1.00)$ & 0.050 & 1 & $0.64(0.78-1.05)$ & 0.079 \\
\hline \multicolumn{6}{|l|}{ Insulin } \\
\hline Mod. 1 & $0.57(0.27-1.18)$ & 0.125 & 1 & $0.47(0.29-0.77)$ & 0.005 \\
\hline Mod. 2 & $0.68(0.35-1.30)$ & 0.230 & 1 & $0.54(0.31-0.93)$ & 0.031 \\
\hline Mod. 3 & $0.62(0.40-0,94)$ & 0.030 & 1 & $0.54(0.32-0.88)$ & 0.017 \\
\hline Mod. 4 & $0.56(0.34-0.94)$ & 0.030 & 1 & $0.53(0.32-0.87)$ & 0.015 \\
\hline
\end{tabular}

Data are expressed as prevalence ratio and 95\% confidence interval (Cl); Poisson regression to Model 1; Group peri-menarche: Less than 2 years since menarche; Group post-menarche: 2 years or more since menarche; Multivariate Poisson regression to models adjusted for chronological age (increase of 1 year); ethnicity (nonwhite), smoking (experimented), alcohol (experimented), waist circumference and nutritional status (overweight and obesity); PR=Prevalence ratios (menarche B in relation to menarche A); $\mathrm{p}$ value $\leq 0.05$ and $95 \% \mathrm{Cl}$; Altered HOMA-IR: $\geq 3.16$; hyperinsulinemia: $>15 \mathrm{mU} / \mathrm{mL}$; Model 1 - unadjusted; Model 2 -adjusted for age and ethnicity; Model 3-adjusted for age, ethnicity, smoking, alcohol, and waist circumference; Model 4-adjusted for age, ethnicity, smoking, alcohol and nutritional status

Statistically significant prevalence ratios are in bold $(p<0.05)$ 
capitals is in line with other studies that described IR as physiological process during puberty [1-6].

Knowledge of factors associated with IR, as well as the identification of population groups at higher risk for chronic non-communicable diseases, is a matter of concern in adolescence [37]. Here, we present robust results of factors associated with IR showing that $\mathrm{Ow} / \mathrm{Ob}$ and WC increased the probability of IR by around five times when compared to eutrophic teenagers.

In fact, changes in insulin sensitivity during puberty seem to be worsened by obesity [2] and the expectation of recovery in insulin sensitivity following puberty, may not occur in obese girls [1-3]. The non-occurrence of insulin sensitivity recovery is supported by the fact that the hypertrophic adipocytes are more susceptible to inflammation, apoptosis, fibrosis, and release of free fatty acids, which is associated with IR [2, 38]. Moreover, central obesity is closely related to glucose intolerance and IR and girls with high WC are at greater risk for type 2 diabetes and cardiometabolic comorbidities than girls with normal WC at the same age $[1,2]$. Thus, our findings suggest that adolescents who did not maintain protection after menarche and who were obese, were exposed to these comorbidities early on.

Currently, studies involving puberty that provide data on IR, most often include Tanner staging or pre-pubertal and pubertal periods [37]. In the present study, we analyzed adolescents from the peri-menarche period, presenting higher prevalence of IR in both capitals, when compared with the group in the post-puberty, with 2 years or more since menarche, a period in which insulin sensitivity could be expected to return [39]. We also found that younger, black adolescents in PoA had a longer exposure to IR.

Unhealthy lifestyle habits are related to metabolic risks in childhood and adolescence [40-42]. Here, we report that in the southern capital, adolescents had less healthy habits, such as being more inactive, with more experimental use of tobacco and alcohol, in addition to having a higher intake of trans-fatty acids. The behavior of adolescents in southern Brazil may be reflecting cultural habits in a more urbanized city, resulting in adolescents being exposed to a higher prevalence of obesity and a sedentary lifestyle and ultra-processed foods [43].

We found that ethnicity was a predictor of change in insulin sensitivity, in which self-declared black adolescents were more likely to have IR. However, for girls aged over 15 years, this analysis did not remain significant. In this perspective, ethnicity has been associated with IR in adults and adolescents [2, 44, 45]. Indeed, preventing or reducing cardio-metabolic risk in African American girls has been recognized as an important public health objective [44]. Also, specifically in Brazil, socioeconomic inequality follows ethnic diversity, however with unclear repercussions on the health outcomes in Brazilian women at different stages of life [46, 47].

The limitations of this study include the possibility of reverse causality, because of its cross-sectional design. Furthermore, this study was conducted retrospectively using data collected for a larger research project. The strengths and relevant points of this study include new data on the prevalence of IR and its possible predictors in female adolescents from two regions in the geographical extremities of Brazil. Another methodological strength was the use of a hierarchical model that included socioeconomic and behavioral factors, nutritional status and association with time since menarche.

\section{Conclusions}

In conclusion, data from this study indicate that IR is more prevalent in the peri-menarche, especially in younger and black adolescents, compared to white and post-menarche adolescents. $\mathrm{Ow} / \mathrm{Ob}$ and high WC were associated with the occurrence of IR independently of age and ethnicity variables. Further research with a longitudinal design is warranted in order to confirm and extend the findings from this study. There is still a need for further clarification on causal associations between environmental and lifestyle factors and IR in adolescent girls from regions with diverse ethnic and socio-cultural characteristics.

\section{Abbreviations}

IR: Insulin resistance; PVh: Porto Velho; PoA: Porto Alegre; HOMA-IR: Homeostasis model assessment for insulin resistance; DM: Diabetes mellitus; ERICA: Study of cardiovascular risks in adolescents; BMI: Body mass index; WC: Waist circumference; PR: Prevalence ratio; Ow/Ob: Overweight/obesity.

\section{Supplementary Information}

The online version contains supplementary material available at https://doi. org/10.1186/s13098-021-00730-8.

Additional file 1: Table S1. Prevalence ratios of insulin resistance according to cities and time since menarche in girls aged 12 to 17 years. Table S2. Prevalence ratio of insulin resistance, stratified by HOMA-IR and insulin in Porto Velho. Table S3. Prevalence ratio of insulin resistance, according to HOMA-IR and insulin in Porto Alegre. Table S4. Characterization of dietary variables according to insulin resistance, in Porto Velho and Porto Alegre, 2013-2014 ( $n=889)$.

Additional file 2: Table S5. Distribution of insulin resistance and insulin according to time of menarche, in the cities of Porto Velho-RO $(n=382)$ and Porto Alegre-RS $(n=507)$.

\section{Acknowledgements}

Not applicable.

\section{Authors' contributions}

All authors participated in the analysis of data and in the writing and reviewing of the manuscript. All authors read and approved the final manuscript. 


\section{Funding}

This study was supported by the Brazilian National Institute of Hormones and Women's Health/Conselho Nacional de Desenvolvimento Científico e Tecnológico (CNPq INCT 465482/2014-7) and Fundação de Amparo à Pesquisa do Rio Grande do Sul (FAPERGS/INCT 17/2551-0000519-8). M.T.A.O. received research funding from Brazilian National Council for Scientific and Technological Development (CNPq, Process n. 440898/2017-0).

\section{Availability of data and materials}

Most of data generated or analyzed during this study are included within the article and its supplementary information file. Any additional data are available from the corresponding author on reasonable request.

\section{Declarations}

\section{Ethics approval and consent to participate}

The study was carried out in accordance with the Declaration of Helsinki. Written informed consent was obtained from each participant and his or her parents/legal guardians before enrolment in the study. This study protocol was review and approved by the Research Ethics Committee (REC) of the Federal University of Rondônia, Federal University of Rio Grande do Sul and the Institute of Studies in Collective Health of the University of Rio de Janeiro (Protocol 45/2008).

\section{Consent for publication}

Not applicable.

\section{Competing interests}

The authors have no conflicts of interest to declare.

\section{Author details}

${ }^{1}$ Federal University of Rio Grande Do Sul (UFRGS), Porto Alegre, Brazil. ${ }^{2}$ Federal University of Rondônia, Rondônia, Brazil. ${ }^{3}$ Gynecological Endocrinology Unit, Division of Endocrinology, Hospital de Clínicas de Porto Alegre (HCPA), Porto Alegre, Brazil. ${ }^{4}$ University of Vale Do Rio Dos Sinos, UNISINOS, São Leopoldo, Brazil. ${ }^{5}$ Department of Physiology, Laboratory of Molecular Endocrinology, Federal University of Rio Grande Do Sul (UFRGS), Porto Alegre, Brazil. ${ }^{6}$ Division of Endocrinology, Hospital de Clínicas de Porto Alegre, Rua Ramiro Barcelos 2350, Porto Alegre, Rio Grande Do Sul 90035-003, Brazil.

Received: 7 August 2021 Accepted: 5 October 2021

Published online: 19 October 2021

\section{References}

1. Kelsey MM, Zeitler PS. Insulin resistance of puberty. Curr Diab Rep. 2016;16(7):64. https://doi.org/10.1007/s11892-016-0751-5.

2. Kelsey MM, Pyle L, Hilkin A, Severn CD, Utzschneider K, Van Pelt RE, et al. The impact of obesity on insulin sensitivity and secretion during pubertal progression: a longitudinal study. J Clin Endocrinol Metab. 2020;105(5):e2061-8. https://doi.org/10.1210/clinem/dgaa043.

3. Amiel SA, Sherwin RS, Simonson DC, Lauritano AA, Tamborlane WV. Impaired insulin action in puberty. A contributing factor to poor glycemic control in adolescents with diabetes. N Engl J Med. 1986;315(4):215-9. https://doi.org/10.1056/NEJM198607243150402.

4. Goran MI, Gower BA. Longitudinal study on pubertal insulin resistance. Diabetes. 2001;50(11):2444-50. https://doi.org/10.2337/diabetes.50.11. 2444.

5. Moran A, Jacobs DR Jr, Steinberger J, Hong CP, Prineas R, Luepker R, et al. Insulin resistance during puberty: results from clamp studies in 357 children. Diabetes. 1999;48(10):2039-44. https://doi.org/10.2337/ diabetes.48.10.2039.

6. Jeffery SC, Hosking J, Jeffery AN, Murphy MJ, Voss LD, Wilkin TJ, et al. Insulin resistance is higher in prepubertal girls but switches to become higher in boys at age 16: a cohort study (EarlyBird 57). Pediatr Diabetes. 2018;19(2):223-30. https://doi.org/10.1111/pedi.12571.
7. World Health Organization. Fact sheets: obesity and overweight. Geneva: WHO Press. 2021. https://www.who.int/news-room/fact-sheets/detail/ obesity-and-overweight. Accessed 20 Jul 2021.

8. Keskin M, Kurtoglu S, Kendirci M, Atabek ME, Yazici C. Homeostasis model assessment is more reliable than the fasting glucose/insulin ratio and quantitative insulin sensitivity check index for assessing insulin resistance among obese children and adolescents. Pediatrics. 2005;115(4):e500-3. https://doi.org/10.1542/peds.2004-1921.

9. Andrade MIS, Oliveira JS, Leal VS, Lima NMS, Bezerra PB, Santiago ERC, et al. Prevalence of insulin resistance and association with metabolic risk factors and food consumption in adolescents-Recife/Brazil. Rev Paul Pediatr. 2020;38: e2019016. https://doi.org/10.1590/1984-0462/2020/38/ 2019016.

10. Gemelli IFB, Farias EDS, Spritzer PM. Association of body composition and age at menarche in girls and adolescents in the Brazilian Legal Amazon. J Pediatr. 2020;96(2):240-6. https://doi.org/10.1016/j.jped.2018.10.012.

11. Biro FM, Greenspan LC, Galvez MP, Pinney SM, Teitelbaum S, Windham GC, Deardorff J, Herrick RL, Succop PA, Hiatt RA, Kushi LH, Wolff MS. Onset of breast development in a longitudinal cohort. Pediatrics. 2013;132(6):1019-27. https://doi.org/10.1542/peds.2012-3773.

12. Manta FSN, Pereira R, Vianna R, Araújo ARB, Gitaí DLG, Silva DA, et al. Revisiting the genetic ancestry of Brazilians using autosomal AIM-Indels. PLoS ONE. 2013;8(9): e75145. https://doi.org/10.1371/journal.pone.00751 45.

13. Pirgon Ö, Aslan N. The role of urbanization in childhood obesity. J Clin Res Pediatr Endocrinol. 2015;7(3):163-7. https://doi.org/10.4274/jcrpe.1984.

14. Bloch KV, Klein CH, Szklo M, Kuschnir MC, Abreu G, Barufaldi LA, et al. ERICA: prevalence of hypertension and obesity in Brazilian adolescents. Rev Saude Publica. 2016;50 Suppl 1(Suppl 1):9s. https://doi.org/10.1590/ S01518-8787.2016050006685.

15. Bloch KV, Szklo M, Kuschnir MC, Abreu G, Barufaldi LA, Klein CH, et al. The study of cardiovascular risk in adolescents_ERICA: rationale, design and sample characteristics of a national survey examining cardiovascular risk factor profile in Brazilian adolescents. BMC Public Health. 2015;15:94. https://doi.org/10.1186/s12889-015-1442-x.

16. World Medical Association. World Medical Association Declaration of Helsinki: ethical principles for medical research involving human subjects. JAMA. 2013;310(20):2191-4. https://doi.org/10.1001/jama.2013.281053.

17. Associação Brasileira de Empresas de Pesquisa. Critério de classificação econômica Brasil. São Paulo: ABEP. 2018. http://www.abep.org/criterioBr/ 01_cceb_2018.pdf. Accessed 20 Jul 2021.

18. Instituto Brasileiro de Geografia e Estatística. Metodologia do censo demográfico de 2000: Série de relatórios metodológicos, 25. Rio de Janeiro: IBGE. https://biblioteca.ibge.gov.br/visualizacao/livros/liv5295. pdf. Accessed 20 Jul 2021.

19. Instituto Brasileiro de Geografia e Estatística. Pesquisa nacional de saúde do escolar: 2012. Rio de Janeiro: IBGE. 2013. https://biblioteca.ibge.gov. br/visualizacao/livros/liv64436.pdf. Accessed 20 Jul 2021.

20. World Health Organization. WHO framework convention on tobacco control: guidelines for implementation of article 5. 3, Articles 8 To 14. Geneva: WHO Press. 2013. https://apps.who.int/iris/bitstream/handle/10665/ 80510/9789241505185_eng.pdf?sequence=1. Accessed 20 Jan 2021.

21. Patton GC, Coffey C, Sawyer SM, Viner RM, Haller DM, Bose K, et al. Global patterns of mortality in young people: a systematic analysis of population health data. Lancet. 2009;374(9693):881-92. https://doi.org/10.1016/ S0140-6736(09)60741-8.

22. Farias JC Jr, Lopes AS, Mota J, Santos MP, Ribeiro JC, Hallal PC. Validade e reprodutibilidade de um questionário para medida de atividade física em adolescentes: uma adaptação do self-administered physical activity checklist [validity and reproducibility of a physical activity questionnaire for adolescents: adapting the self-administered physical activity checklist]. Rev Bras Epidemiol. 2012;15(1):198-210. https://doi.org/10.1590/ s1415-790x2012000100018.

23. American Academy of Pediatrics, Committee on Public Education. American academy of pediatrics: children, adolescents, and television. Pediatrics. 2001;107(2):423-6. https://doi.org/10.1542/peds.107.2.423.

24. Lemarchand-Béraud T, Zufferey MM, Reymond M, Rey I. Maturation of the hypothalamo-pituitary-ovarian axis in adolescent girls. J Clin Endocrinol Metab. 1982;54(2):241-6. https://doi.org/10.1210/jcem-54-2-241.

25. Ministério da Saúde, Secretaria de Atenção à Saúde, Departamento de Atenção Básica. Orientações para a coleta e análise de dados 
antropométricos em serviços de saúde: Norma Técnica do Sistema de Vigilância Alimentar e Nutricional - SISVAN / Ministério da Saúde, Secretaria de Atenção à Saúde, Departamento de Atenção Básica. Brasília: Ministério da Saúde. 2011. http://bvsms.saude.gov.br/bvs/publicacoes/ orientacoes_coleta_analise_dados_antropometricos.pdf. Accessed $20 \mathrm{Jul}$ 2021.

26. World Health Organization. Physical status: the use of and interpretation of anthropometry, report of a WHO Expert Committee. Geneva: WHO Press. 1995. https://apps.who.int/iris/bitstream/handle/10665/37003/ WHO_TRS_854.pdf. Accessed 20 Jul 2021.

27. International Diabetes Federation: global guideline for type 2 diabetes. Brussels: international diabetes federation. 2012. https://www.idf. org/e-library/guidelines/79-global-guideline-for-type-2-diabetes.html. Accessed 20 Jul 2021.

28. Barufaldi LA, de Azevedo Abreu G, da Veiga GV, et al. Software to record 24-hour food recall: application in the study of cardiovascular risks in adolescents. Rev Bras Epidemiol. 2016;19(2):464-8. https://doi.org/10. 1590/1980-5497201600020020.

29. de M Souza A, Pereira RA, Yokoo EM, et al. Most consumed foods in Brazil: national dietary survey 2008-2009. Rev Saúde Pública. 2013;47(Suppl. 1):190s-9s. https://doi.org/10.1590/S0034-89102013000700005.

30. Instituto Brasileiro de Geografia e Estatística. Pesquisas de Orçamentos Familiares 2008-2009: Análise do Consumo Alimentar Pessoal no Brasil. Rio de Janeiro: IBGE. 2011. https://biblioteca.ibge.gov.br/visualizacao/ livros/liv50063.pdf. Accessed 20 Jul 2021.

31. Meyers LD, Hellwig JP, Otten JJ,editors. Dietary reference intakes: the essential guide to nutrient requirements. Washington DC: National Academies Press. 2006. https://www.nal.usda.gov/sites/default/files/fnic uploads/DRIEssentialGuideNutReq.pdf. Accessed 20 Jul 2021.

32. Cureau FV, Bloch KV, Henz A, Schaan CW, Klein CH, Oliveira CL, et al. Challenges for conducting blood collection and biochemical analysis in a large multicenter school-based study with adolescents: lessons from ERICA in Brazil. Cad Saude Publica. 2017;33(4): e00122816. https://doi.org/ 10.1590/0102-311X00122816.

33. Matthews DR, Hosker JP, Rudenski AS, Naylor BA, Treacher DF, Turner RC. Homeostasis model assessment: insulin resistance and beta-cell function from fasting plasma glucose and insulin concentrations in man. Diabetologia. 1985;28(7):412-9. https://doi.org/10.1007/BF00280883.

34. Giuliano IDCB, Caramelli B, Pellanda LC, Duncan BB, Mattos S, Fonseca FAH. I Diretriz de Prevenção da Aterosclerose na Infância e na Adolescência. Arq Bras Cardiol. 2005;85:3-36. https://doi.org/10.1590/50066-782X2 005002500001.

35. Victora CG, et al. The role of conceptual frameworks in epidemiological analysis: a hierarchical approach. Int J Epidemiol. 1997;26(1):224-7. https://doi.org/10.1093/ije/26.1.224.

36. van der Aa MP, Fazeli Farsani S, Knibbe CA, de Boer A, van der Vorst MM. Population-based studies on the epidemiology of insulin resistance in children. J Diabetes Res. 2015;2015: 362375. https://doi.org/10.1155/ 2015/362375.

37. Marshall WA, Tanner JM. Variations in pattern of pubertal changes in girls. Arch Dis Child. 1969:44(235):291-303. https://doi.org/10.1136/adc.44.235. 291.
38. Spritzer PM, Lecke SB, Satler F, Morsch DM. Adipose tissue dysfunction, adipokines, and low-grade chronic inflammation in polycystic ovary syndrome. Reproduction. 2015;149(5):R219-27. https://doi.org/10.1530/ REP-14-0435.

39. Kurtoğlu S, Hatipoğlu N, Mazıcıoğlu M, Kendirici M, Keskin M, Kondolot M. Insulin resistance in obese children and adolescents: HOMA-IR cut-off levels in the prepubertal and pubertal periods. J Clin Res Pediatr Endocrinol. 2010;2(3):100-6. https://doi.org/10.4274/jcrpe.v2i3.100.

40. Sousa Carvalho L, Santos MM. Dislipidemias e obesidade em adolescentes: uma revisão de literatura. Rev Eletrônica Acervo Saúde. 2019;36:e1361-e1361. https://doi.org/10.25248/reas.e1361.2019.

41. Kahleova H, Hlozkova A, Fleeman R, Fletcher K, Holubkov R, Barnard ND. Fat quantity and quality, as part of a low-fat, vegan diet, are associated with changes in body composition, insulin resistance, and insulin secretion. A 16-week randomized controlled trial. Nutrients. 2019;11(3):615. https://doi.org/10.3390/nu11030615.

42. Lamounier JA, Abrantes MM. Prevalência de obesidade e sobrepeso na adolescência no Brasil. Rev Med Minas Gerais. 2003;13(4):275-84. https:// doi.org/10.1590/s0104-42302003000200034.

43. Noll PRES, Noll M, de Abreu LC, Baracat EC, Silveira EA, Sorpreso ICE. Ultra-processed food consumption by Brazilian adolescents in cafeterias and school meals. Sci Rep. 2019;9(1):7162. https://doi.org/10.1038/ s41598-019-43611-x.

44. Bleil ME, Booth-LaForce C, Benner AD. Race disparities in pubertal timing: implications for cardiovascular disease risk among African American women. Popul Res Policy Rev. 2017;36(5):717-38. https://doi.org/10.1007/ s11113-017-9441-5.

45. Raygor V, Abbasi F, Lazzeroni LC, et al. Impact of race/ethnicity on insulin resistance and hypertriglyceridaemia. Diab Vasc Dis Res. 2019;16(2):153-9. https://doi.org/10.1177/1479164118813890.

46. Carone I, Bento MAS. Psicologia social do racismo: estudos sobre branquitude e branqueamento no Brasil. Petrópolis: Editora Vozes Limitada; 2017.

47. de Neves Manta FS, Pereira R, Vianna R, et al. Revisiting the genetic ancestry of Brazilians using autosomal AIM-Indels. PLoS ONE. 2013;8(9): e75145. https://doi.org/10.1371/journal.pone.0075145.

48. International Diabetes Federation. The IDF consensus worldwide definition of the Metabolic Syndrome, 2006. https://www.idf.org/e-library/ consensus-statements/60-idfconsensus-worldwide-definitionof-themetabolicsyndrome.html. Accessed 12 Oct 2021.

49. World Health Organization. Growth reference data for 5-19 years, 2007. https://www.who.int/tools/growthreference-data-for-5to19-years. Accessed 12 Oct 2021.

50. Diretriz de prevenção da aterosclerose na infância e adolescência. Arq Bras Cardiol. 2005;85(Suppl. 6):1-36. https://doi.org/10.1590/S0066-782X2 005002500001

\section{Publisher's Note}

Springer Nature remains neutral with regard to jurisdictional claims in published maps and institutional affiliations. 